\title{
Development of a real-time PCR method for rapid diagnosis of canine babesiosis and anaplasmosis
}

Agnija Kivrane, Agne Namina, Maija Seleznova, Sarmite Akopjana, Valentina Capligina and Renate Ranka*

\begin{abstract}
Background: Canine babesiosis and anaplasmosis, caused by Babesia canis and Anaplasma phagocytophilum, respectively, are significant tick-borne diseases in Baltic countries. Both diseases can be diagnosed on the basis of clinicopathological findings, by direct pathogen detection in blood smears or by indirect pathogen detection; however, because of high selectivity and specificity, molecular methods may be advantageous. The goal of this study was to develop a duplex real-time polymerase chain reaction (RT-PCR) method for the detection of B. canis and A. phagocytophilum in canine clinical samples.
\end{abstract}

Methods: Sequence-based polymorphism analysis of genes encoding $B$. canis-specific merozoite surface protein $B c 28.1$ (Bc28.1) and A. phagocytophilum malate dehydrogenase ( $m d h)$ was performed on pathogen isolates present in Latvian domestic dogs. The obtained results were used to design a species-specific duplex RT-PCR assay.

Results: The presence of three $B$. canis $B c 28.1$ gene sequence types was revealed in canine samples with a nonuniform geographical distribution, and two types of $A$. phagocytophilum mdh genes were detected. The novel duplex RT-PCR assay provided correct classification of samples positive and negative for $B$. canis and $A$. phagocytophilum. The analytical sensitivity of this assay was ten gene copies/ reaction for both pathogens.

Conclusions: A novel duplex RT-PCR molecular method was developed for the detection of B. canis and A. phagocytophilum in canine clinical samples. Sequence variability of $B c 28.1$ and mdh genes indicated the genetic variability of $B$. canis and A. phagocytophilum isolates occurring in Latvian domestic dogs.

Keywords: Babesia canis, Anaplasma phagocytophilum, Genotyping, Bc28.1 gene, Mdh gene, Real-time PCR

\section{Background}

Canine babesiosis is an important tick-borne disease caused by species of the genus Babesia [1]. Clinical manifestations vary, and the disease can be lethal if left untreated [2]. In the last decade, canine babesiosis has been established as an endemic disease with a seasonal pattern in the Baltic countries of Lithuania

*Correspondence: renate_r@biomed.lu.lv

Latvian Biomedical Research and Study Centre, Ratsupites Street 1, Riga, Latvia and Latvia and is associated with the spread of the tick vector Dermacentor reticulatus [3-6]. Molecular testing has shown that Babesia canis was the sole causative agent of the disease in published canine babesiosis case reports from Latvia, Lithuania and Estonia [5, 7-9]. Another tick-borne pathogen of veterinary significance is the gram-negative intracellular bacterium Anaplasma phagocytophilum, which is transmitted mainly by Ixodes spp. ticks and has important zoonotic potential [10]. Studies performed in Europe showed that 3 to $57 \%$ of dogs were exposed to A. phagocytophilum [11]. In Latvia, the reported 
seroprevalence of anaplasmosis in dogs is $11-17 \%$ [12]. In a recent large-scale countrywide study, $A$. phagocytophilum was identified at similar proportions in field-collected Latvian I. ricinus, I. persulcatus and Dermacentor reticulatus ticks, with an overall prevalence of $1.09 \%$ [13].

Rapid diagnosis and differentiation of both infections is highly important for timely initiation of effective treatment [14]. The direct blood smear detection method is not sensitive enough to detect either $A$. phagocytophilum or $B$. canis, while serological testing is not informative because it is not suitable in the acute phase of the infection, does not distinguish between ongoing disease and previous exposure, and cross-reactivity could interfere with the specificity of the test $[2,11,14]$. Molecular testing has been shown to be appropriate and advantageous because of improved diagnostic specificity and sensitivity $[1,11]$. For molecular detection of Babesia spp., numerous genus- and species-specific polymerase chain reaction (PCR)-based methods have been reported that target various genes, including $18 \mathrm{~S}$ ribosomal RNA, cytochrome c oxidase 1 (COX1) and internal transcribed spacers (ITS) [15-19]. Molecular assays for A. phagocytophilum are mostly based on the amplification of the $16 S$ ribosomal RNA and groESL heat shock operon genes [20-22]. Real-time polymerase chain reaction (RT-PCR) methods were highlighted as more convenient and time-saving for clinical applications, and several singleplex and multiplex RT-PCR assays for detecting Babesia spp. and A. phagocytophilum in clinical samples have been reported; however, none of them were tested for simultaneous detection and differentiation of $B$. canis and A. phagocytophilum infections in clinical samples [23-28]. Both canine babesiosis and anaplasmosis are present in Latvia and elsewhere in Europe; in addition, the risk of coinfection exists because of the sympatric occurrence of the principal vectors of canine babesiosis and anaplasmosis, I. ricinus and D. reticulatus [13].

In the present study, sequence-based polymorphism analysis of genes encoding $B$. canis-specific merozoite surface protein Bc28.1 (Bc28.1) and A. phagocytophilum malate dehydrogenase $(m d h)$ was performed. The obtained results were used to design a species-specific duplex RT-PCR assay for the rapid detection and discrimination of $B$. canis and A. phagocytophilum in dogs.

\section{Methods \\ Samples}

The blood samples from dogs used in this study were collected by Latvian veterinarians. The first sample set comprised 262 clinical samples submitted during the period from 2016 to 2019 [5]. Five samples were excluded because of insufficient amounts of DNA. The second clinical sample set $(n=94$ samples) was submitted by veterinarians for molecular testing from 2011 to 2014.

DNA isolation from clinical samples was performed as described previously by Berzina et al. [12]. All clinical samples were screened by seminested PCR targeting the $18 S$ rRNA gene fragment for Babesia spp. [17] and species-specific nested PCR targeting $16 S$ rRNA gene fragments for A. phagocytophilum [22]. Babesia spp. infection was confirmed, and pathogens were identified by sequencing the amplification products. As a negative control, PCR mixtures without DNA were used. As positive controls for PCR, the following specimens were used: A. phagocytophilum Webster strain (kindly donated by Friederike von Loewenich, Institute of Medical Microbiology, University of Freiburg, Germany) and B. canis-positive clinical sample Lv-dog 2 (positive DNA sample from dog blood), which was obtained in a previous study [8].

B. canis- and A. phagocytophilum-positive clinical samples were further used for $B c 28.1$ and $m d h$ gene polymorphism analysis, respectively. Both clinical sample sets were used for the specificity assessment of the novel RT-PCR method. Theileria annae (B. vulpes)-positive DNA samples were kindly donated by Prof. Andrei D. Mihalca, University of Agricultural Sciences and Veterinary Medicine of Cluj-Napoca, Romania. Ehrlichia canis- and A. platys-positive DNA samples were kindly donated by Assoc. Prof. Hui-Wen Chen, National Taiwan University, Taiwan.

\section{PCR amplification and sequencing of $B$. canis $B C 28.1$ and $A$. phagocytophilum mdh genes}

The full-length $B c 28.1$ gene of $B$. canis was amplified using PCR in B. canis-positive clinical samples according to the protocol by Carcy et al. [29] with a few minor modifications. The oligonucleotide primer pair F5'UTR281\&2/R3'UTR281 was used for amplification of the 852-nt-long $B c 28.1$ gene fragment (Table 1) [29]. For each PCR, $26 \mu$ l of the reaction mixture was prepared, which consisted of $1 \times$ reaction buffer BD with $\left(\mathrm{NH}_{4}\right)_{2} \mathrm{SO}_{4}$ and Tris- $\mathrm{HCl}, 2.5 \mathrm{mM}$ $\mathrm{MgCl}_{2}, 0.2 \mathrm{mM}$ for each dNTP, $0.2 \mu \mathrm{M}$ for each primer, $0.8 \mathrm{U}$ of FIREPol DNA polymerase and $2 \mu \mathrm{l}$ of target DNA. Amplification was performed at the following temperatures: initial denaturation at $94{ }^{\circ} \mathrm{C}$ for $3 \mathrm{~min}$, followed by 35 amplification cycles $\left(94{ }^{\circ} \mathrm{C}\right.$ for $30 \mathrm{~s}, 55{ }^{\circ} \mathrm{C}$ for $30 \mathrm{~s}, 72{ }^{\circ} \mathrm{C} 60 \mathrm{~s}$ ), and a final extension step at $72{ }^{\circ} \mathrm{C}$ for $7 \mathrm{~min}$. 
The 593-bp fragment of $m d h$ gene of A. phagocytophilum, which is a highly conserved housekeeping gene used for multilocus sequence typing (MLST) analysis, was amplified using the PCR primers mdh $1 \mathrm{fa}$ and mdh 2ra according to the MLST database (http://pubmlst.org/aphagocytophilum) (Table 1) [30]. For each PCR, $26 \mu \mathrm{l}$ of the reaction mixture was prepared, which consisted of $1 \times$ Phusion HF Buffer (with $7.5 \mathrm{mM} \mathrm{MgCl}_{2}$ ), $0.2 \mathrm{mM}$ for each dNTP, $0.3 \mu \mathrm{M}$ for each primer, 0.4 $\mathrm{U}$ of Phusion Hot Start II HighFidelity DNA Polymerase and $2 \mu \mathrm{l}$ of target DNA. Amplification was performed at the following temperatures: initial denaturation at $98^{\circ} \mathrm{C}$ for $3 \mathrm{~min}$, followed by 40 amplification cycles $\left(98^{\circ} \mathrm{C}\right.$ for $20 \mathrm{~s}, 65^{\circ} \mathrm{C}$ for $30 \mathrm{~s}, 72{ }^{\circ} \mathrm{C} 60 \mathrm{~s}$ ) and a final extension step at $72{ }^{\circ} \mathrm{C}$ for $5 \mathrm{~min}$.

All PCRs were performed by using Mastercycler epgradient S (Eppendorf AG, Hamburg, Germany). Negative PCR controls (PCR mixtures without DNA) were included in each run. The obtained PCR products were analyzed by agarose gel electrophoresis in a $1.5 \%$ agarose gel with $0.2 \mu \mathrm{g}$ of ethidium bromide/ $\mathrm{ml}$. If necessary, amplification products were stored at $-20^{\circ} \mathrm{C}$ until further analysis.

BrilliantDye Terminator Cycle Sequencing Kit v1.1 (NimaGen, Nijmegen, Netherlands) was used to sequence the amplification products. Sequencing was carried out according to a standard protocol using an ABI Prism 3100 Genetic Analyzer (PerkinElmer, Waltham, MA, USA). The MEGA and FinchTV programs and ClustalW alignment algorithm [31] were used for sequence alignment and analysis; Basic Logical Alignment Search Tool (BLAST, https://blast.ncbi. nlm.nih.gov/Blast.cgi) was used for sequence comparison to previously published data in GenBank. The obtained B. canis Bc28.1 gene sequence types were submitted to GenBank with the following accession numbers: MN832760, MN832761 and MN832762. The obtained A. phagocytophilum $m d h$ gene sequences were submitted to GenBank with the following accession numbers: MW822581, MW822582, MW822583, MW822584, MW822585 and MW822586.

\section{Phylogenetic analysis of $B$. canis $B \subset 28.1$ and $A$. phagocytophilum mdh genes}

$B$. canis $B c 28.1$ gene sequence types were distinguished on the basis of nucleotide substitutions according to a previously reported classification [30]. All available $B$. canis $B c 28.1$ gene sequences were retrieved from GenBank $(n=18$; assessed on 1 September 2020). Phylogenetic analysis was performed using 57 nucleotide sequences, including 39 sequences from this study; the heterogeneous isolate was omitted. A. phagocytophilum $m d h$ gene alleles were distinguished on the basis of nucleotide substitutions according to the A. phagocytophilum MLST database [30]. All available A. phagocytophilum mdh sequences were retrieved from the MLST database (520 isolates and 42 alleles; database was accessed on 1 September 2020). Identical sequences from the same country were merged, and detailed information about the total number and origin of these samples was indicated next to the branch in the phylogenetic tree. The final phylogenetic analysis involved 79 nucleotide sequences, including 6 sequences from this study. The most suitable evolutionary model was determined in MEGA based on the lowest (Bayesian information criterion, BIC) scores. The evolutionary history for the $B$. canis $B c 28.1$ gene was inferred by using the maximum likelihood method based on the Jukes-Cantor model [32]. The evolutionary history for A. phagocytophilum $m d h$ gene was inferred by using the maximum likelihood method based on the Hasegawa-Kishino-Yano model [33]. Phylogenetic analysis was conducted in MEGA7 [34]. The phylogenetic trees were midpoint rooted.

\section{Preparation of plasmid standard controls by molecular cloning}

The full-length $B$. canis $B c 28.1$ gene and partiallength $A$. phagocytophilum $m d h$ gene were amplified by PCR using the F5'UTR281\&2/R3'UTR281 primer pair and mdh $1 \mathrm{fa} / \mathrm{mdh} 2$ ra primer pair, respectively (Table 1). For each PCR, $25 \mu \mathrm{l}$ of the reaction mixture was prepared, which consisted of $1 \times$ Phusion HF Buffer with $\mathrm{MgCl}_{2}, 0.2 \mathrm{mM}$ for each dNTP, $0.3 \mu \mathrm{M}$ for each primer, 0.4 U of Phusion Hot Start II High Fidelity DNA Polymerase and $2 \mu \mathrm{l}$ of target DNA. Amplification was performed at the following temperatures: initial denaturation at $98{ }^{\circ} \mathrm{C}$ for $30 \mathrm{~s}$, followed by 35 amplification cycles $\left(98^{\circ} \mathrm{C}\right.$ for $10 \mathrm{~s}, 62^{\circ} \mathrm{C}(m d h$ gene) $/ 60{ }^{\circ} \mathrm{C}$ ( $B c 28.1$ gene) for $30 \mathrm{~s}, 72{ }^{\circ} \mathrm{C} 30 \mathrm{~s}$ ), and a final extension step at $72{ }^{\circ} \mathrm{C}$ for $5 \mathrm{~min}$. The obtained amplification products were analyzed by agarose gel electrophoresis. If necessary, amplification products were stored at $-20^{\circ} \mathrm{C}$ until further analysis.

The PCR products were cloned into the pJET1.2/ blunt cloning vector using the CloneJET PCR Cloning Kit (Thermo Fisher Scientific, USA) according to the manufacturer's instructions. Plasmids with confirmed $B c 28.1$ and $m d h$ gene inserts were purified from bacterial cultures. DNA concentration and purity were assessed using a NanoDrop spectrometer (Thermo Fisher Scientific, USA), and DNA copy number was calculated using a Thermo Fisher Scientific DNA Copy Number and Dilution Calculator (https://www. 
thermofisher.com/lv/en/home/brands/thermo-scien tific/molecular-biology/molecular-biology-learn ing-center/molecular-biology-resource-library/ thermo-scientific-web-tools/dna-copy-numbercalculator.html).

Recombined plasmids were spiked with uninfected canine gDNA $(\sim 30 \mathrm{ng} / \mu \mathrm{l})$ and used as positive controls and for validation of the RT-PCR assay.

\section{Design of species-specific duplex RT-PCR assay}

Primers and probes were designed using the onlinebased Primer-BLAST tool (https://www.ncbi.nlm.nih. gov/tools/primer-blast/). All primers and probes were inspected for hairpin and dimer formation. To achieve optimal performance of the assay, various primer and probe concentrations were tested (data not shown).

For the B. canis assay, primers and probes were created on the basis of sequence alignment, which comprised $B c 28.1$ gene sequences from this study and the GenBank database. The primer pair BCF3/BCR3 and $\mathrm{BC} 28$ probes were designed to amplify 65 -bplong gene fragments, which did not involve any polymorphic sites (Table 1). For the A. phagocytophilum assay design, sequences of $m d h$ gene alleles $(n=42)$ from the A. phagocytophilum MLST database were exported and aligned. Primers APmdhF/APmdhR and probe APmdhP were designed to amplify 100-bp-long gene fragments at the most conserved part of the gene (Table 1).

Primers and probes were synthesized by Metabion International AG, Germany. The RT-PCR mixture consisted of $1 \times$ TaqMan Fast Advanced Master Mix (Thermo Fisher Scientific, USA), 0.4 $\mu \mathrm{M}$ Hex-labeled APmdhP probe, $0.5 \mu \mathrm{M}$ APmdhF/APmdhR primers, $0.25 \mu \mathrm{M}$ Fam-labeled BC28 probe and BCF3/BCR3 primers, $2-5 \mu \mathrm{l}$ of target DNA and nuclease-free water to a final volume of $20 \mu \mathrm{l}$. The thermocycler conditions were adjusted considering the manufacturer's recommendations, and the primer and probe melting temperatures were calculated. To prevent contamination, uracil-DNA glycosylase (UNG) was added to the reaction mixtures. Amplification was performed at the following temperatures: UNG pretreatment at $50{ }^{\circ} \mathrm{C}$ to avoid possible reamplification of carryover amplification products and initial denaturation at $95^{\circ} \mathrm{C}$ for $20 \mathrm{~s}$, followed by 35 amplification cycles $\left(95^{\circ} \mathrm{C}\right.$ for $1 \mathrm{~s}, 60{ }^{\circ} \mathrm{C}$ for $20 \mathrm{~s}$, data acquisition). Plasmid standard controls and negative controls were included in each run. For RT-PCR assays and data collection and analysis, QuantStudio ${ }^{\mathrm{TM}} 7$ Flex Real-Time PCR System and QuantStudio ${ }^{\mathrm{TM}}$ Real-Time PCR Software v1.3. (Thermo Fisher Scientific, USA) were used.

\section{Validation of species-specific duplex RT-PCR assay}

The linearity and efficiency $(\varepsilon)$ of the novel RT-PCR method were defined using serial tenfold dilutions of standard controls with concentrations ranging from 80 to $8,000,000$ gene copies per reaction. Serial dilutions consisted of plasmid controls diluted in uninfected canine gDNA $(\sim 30 \mathrm{ng} / \mathrm{ul})$. Each dilution contained both target DNA standards. Three runs under repeatable conditions were performed. Standard curves for both pathogens were constructed by plotting the threshold cycle $\left(C_{t}\right)$ versus target gene copies per reaction. To prevent contamination, UNG was added to the reaction mixture. Negative controls were included in each run. Linear regression analysis was performed by QuantStudio ${ }^{\mathrm{TM}}$ Real-Time PCR Software. The amplification efficiency $(\varepsilon)$ was calculated according to the formula: $\varepsilon=100 \times 10^{-1 / s^{\prime} \text { epe }}-1$.

Analytical sensitivity was characterized using the lower limit of detection (LOD) or lowest concentration of target DNA at which $95 \%$ of samples were

Table 1 Primers and probes used in this study

\begin{tabular}{|c|c|c|c|c|}
\hline Target gene & Primer/probe name & Sequence $\left(5^{\prime}-3^{\prime}\right)$ & Product size & References \\
\hline \multirow[t]{2}{*}{ B.canis Bc28.1 } & F5'UTR281\&2 & AGTCGATACCTCCGAGAATAG & $852 \mathrm{nt}$ & {$[29]$} \\
\hline & R3'UTR281 & CATTACGCCCACAAA TAGTCA & & {$[29]$} \\
\hline \multirow[t]{2}{*}{ A. phagocytophilum mdh } & mdh $1 \mathrm{fa}$ & GTGTTGCGGGTATCTGTCA & $593 \mathrm{nt}$ & {$[30]$} \\
\hline & mdh 2ra & TCCTCCCTTGCGAGTCCT & & {$[30]$} \\
\hline \multirow[t]{3}{*}{ B.canis $B c 28$} & $\mathrm{BC} 28 \mathrm{~F} 3$ & GCTACGTCCGTTGAAGCC & $65 \mathrm{nt}$ & This study \\
\hline & BC28R3 & TCAGCGGAATAACGTTCAGC & & This study \\
\hline & $\mathrm{BC} 28$ & Fam-AGCCAGTCGATCTGCTCCTTTAAGCT & & This study \\
\hline \multirow[t]{3}{*}{ A. phagocytophilum mdh } & APmdhF & CAGACTATGCAGCTATTGAGGG & $100 \mathrm{nt}$ & This study \\
\hline & APmdhR & GCATTAGCCATGAGCAAATCTTC & & This study \\
\hline & APmdhProbe & Hex-TCCTTTCTAGGAAGGCCTGC & & This study \\
\hline
\end{tabular}


detected as positive. To determine the LOD at the nonlinear range of the assay, 5 and 10 gene copies/ reaction in canine gDNA $(\sim 30 \mathrm{ng} / \mathrm{ul})$ were chosen. Each dilution contained both target DNA standards. Twenty intra-assay replicates for each concentration under repeatable conditions were analyzed. Negative controls were included in each run.

Clinical specificity was evaluated by analyzing two independent and characterized clinical sample sets ( $n=257$ and $n=94$ ) that included B. canis- and $A$. phagocytophilum-positive and -negative clinical samples. The obtained RT-PCR results were compared to the PCR results mentioned before. The possible crossreactivity of the assay was assessed by using $B$. vulpes $(n=8)-$, E. canis $(n=3)$ - and A. platys $(n=3)$-positive samples. Additionally, for PCR product size confirmation, 20 randomly chosen RT-PCR amplification products of clinical samples were analyzed by $2.0 \%$ agarose gel electrophoresis (data not shown).

\section{Results}

Molecular analysis of sample sets

For the first sample set, molecular screening revealed 40 B. canis- and 5 A. phagocytophilum-positive clinical samples, and 212 samples were characterized as uninfected. The second clinical sample set contained two $B$. canis and one A. phagocytophilum-positive clinical samples and 91 uninfected samples.

\section{Polymorphism analysis of the $B$. canis $B c 28.1$ gene}

Full-length $B c 28.1$ gene sequences were obtained from $40 \mathrm{~B}$. canis-positive clinical samples. Analysis of the $B c 28.1$ gene sequences revealed 24 polymorphic sites that allowed the classification of $B$. canis isolates into three groups corresponding to three sequence types: D197, D93 and D109 (group names were chosen according to the representative samples) (Table 2; Fig. 1). The $B c 28.1$ sequence type detected in the B. canis isolate D197 was identical to the A8 genotype previously reported by Carcy and colleagues [29]; in total, this sequence type was detected in 25 $(62.5 \%)$ samples. The $B c 28.1$ sequence type of the $B$. canis isolate D93 was closely related but not identical (three nucleotide difference) to the 34.01 genotype previously reported by Carcy and colleagues [29] (Table 2; Fig. 1); it was detected in 13 (32.5\%) samples; $1 \mathrm{~B}$. canis sample was heterozygous. The $B c 28.1$ gene sequence variant of the D109 sample has not been reported previously; in phylogenetic analysis, it clustered together with three B. canis isolates from Lithuania (isolates $19 \mathrm{Kr}, 15 \mathrm{Sn}$ and $21 \mathrm{Sn}$ ) (Fig. 1).
The geographical distribution of $B$. canis $B c 28.1$ sequence types in Latvia was further evaluated. The results showed that the $B$. canis A8/D197 type was mainly detected in Riga and the Riga regions (21 of 25 samples), while the 34.01-like/D93 type was detected in different regions of the country; most often, this sequence type was observed in the Daugavpils region (Fig. 2). B. canis sample D109 was obtained near the Lithuanian border.

\section{Phylogenetic analysis of the A. phagocytophilum mdh gene}

Partial-length (593 bp) $m d h$ gene sequences were obtained from six A. phagocytophilum-positive clinical samples. Sequence-based phylogenetic analysis revealed that five $A$. phagocytophilum isolates from Latvian dogs carried the MLST-based $m d h$ gene allele 2 and one sample carried the $m d h$ gene allele 3 ; both allele clusters contained numerous $A$. phagocytophilum isolates from Europe (Fig. 3). All but one A. phagocytophilum-positive canine clinical sample, including that of the $m d h$ gene allele 3 cluster, was obtained in the Riga region; one sample was obtained in Daugavpils (Fig. 2).

\section{Linearity $\left(R^{2}\right)$ and efficiency $(\varepsilon)$ of the novel duplex RT-PCR assay}

$B$. canis $B c 28.1$ sequences obtained in this study along with A. phagocytophilum $m d h$ gene sequences were further used for novel species-specific duplex RTPCR assay design. During the validation step, linear regression analysis of the obtained data for each target demonstrated linearity $R^{2}>0.99$ for both pathogens within the range of 80 to $8,000,000$ gene copies per reaction (Additional file 1: Fig. S1). The efficiency of the novel assay for B. canis was $103.1 \%$, and that for $A$. phagocytophilum was $102.2 \%$.

\section{Analytical sensitivity (LOD) of the RT-PCR assay}

Analytical sensitivity for both targets (LOD) was tested by using 20 intra-assay replicates at two concentration levels: 5 and 10 gene copies per reaction. For both pathogens, ten gene copies per reaction resulted in $100 \%$ detection, while five gene copies per reaction were detected as positive only in $90 \%$ of cases for B. canis and $70 \%$ for A. phagocytophilum (Table 3). It was concluded that the LOD for the new RT-PCR method was ten gene copies per reaction for both pathogens. 
Table 2 Polymorphism analysis of B. canis Bc28.1 gene in canine babesiosis samples

\begin{tabular}{|c|c|c|c|c|c|c|c|c|c|c|c|c|c|c|}
\hline \multirow[t]{2}{*}{ Genotype } & \multicolumn{14}{|c|}{ Nucleotide positions $^{b}$} \\
\hline & 26 & 35 & 36 & 38 & 129 & 242 & 248 & 259 & 314 & 316 & 412 & 493 & 494 & 505 \\
\hline Isolate A8 (CS019629.1) & G & C & $\mathrm{T}$ & $\mathrm{T}$ & G & G & A & G & G & $A$ & C & A & G & A \\
\hline Isolate D197 & G & C & $\mathrm{T}$ & T & G & G & A & G & G & A & C & A & G & A \\
\hline Isolate $34.01($ KP863714.1) & A & $T$ & C & C & $C$ & A & C & A & G & G & $\mathrm{T}$ & $C$ & A & $T$ \\
\hline Isolate D93 & A & $\mathrm{T}$ & C & C & C & G & C & G & G & G & $\mathrm{T}$ & C & A & $\mathrm{T}$ \\
\hline Isolate D109 & $A$ & $\mathrm{~T}$ & $\mathrm{~T}$ & C & G & G & C & G & A & A & $\mathrm{T}$ & C & A & $\mathrm{T}$ \\
\hline \multirow[t]{2}{*}{ Isolate B (KP863713.1) } & A & $\mathrm{T}$ & $\mathrm{T}$ & C & G & G & C & G & G & A & $\mathrm{T}$ & C & A & $\mathrm{T}$ \\
\hline & 586 & 599 & 634 & 643 & 684 & 692 & 693 & 694 & 739 & 815 & & & & \\
\hline Isolate A8 (CS019629.1) & C & C & A & $\mathrm{T}$ & C & G & A & G & C & G & & & & \\
\hline Isolate D197 & C & C & $A$ & T & C & G & A & G & C & G & & & & \\
\hline Isolate $34.01($ KP863714.1) & A & G & $T$ & C & A & del & del & del & A & C & & & & \\
\hline Isolate D93 & A & $C$ & $\mathrm{~T}$ & C & A & del & del & del & A & $\mathrm{C}$ & & & & \\
\hline Isolate D109 & $A$ & C & $T$ & C & A & del & del & del & C & G & & & & \\
\hline Isolate B (KP863713.1) ${ }^{\mathrm{a}}$ & $A$ & C & $\mathrm{T}$ & C & $C$ & G & $A$ & G & A & C & & & & \\
\hline
\end{tabular}

${ }^{a}$ Isolates described in Carcy et al. 2015 [19]

${ }^{b}$ Nucleotide positions according to the reference sequences CS019629.1 (Bc28.1 gene)

\section{Clinical specificity of the RT-PCR assay}

The clinical specificity of the new RT-PCR assay was evaluated by analysis of two previously characterized clinical sample sets. In total, 351 clinical samples were tested, and the newly developed RT-PCR method demonstrated excellent accuracy, producing no falsepositive or false-negative results (Table 4$)$. B. vulpes $(n=8)-$, E. canis $(n=3)$ - and A. platys $(n=3)$-positive samples did not show a positive signal (Additional file 2: Fig. S2). According to the PCR results, the novel RT-PCR assay provided correct classification of both B. canis- and A. phagocytophilum-positive and -negative samples.

\section{Discussion}

Initially, for this study, we performed polymorphism analysis of the $B c 28.1$ and $m d h$ genes to determine the most suitable target regions for the novel RT-PCR method. The obtained results revealed sequence variability, which indicated the presence of genetically diverse $B$. canis and A. phagocytophilum isolates in canine clinical samples in Latvia. Interestingly, $B$. canis isolates belonging to the two main groups appeared in geographically separate locations, possibly indicating two separate events in the establishment of B. canis foci in Latvia. The predominant Bc28.1 sequence type D197, which was mainly detected in the Riga and Riga regions, fully matched the previously reported $B$. canis A8 genotype (reference sequence CS019629.1 published in GenBank), whose prevalence in Europe was shown to increase from the south to center to north and from west to east [29]. This finding could provide novel data on B. canis expansion events in Europe. The other two sequence types have not been previously reported, while differences in $B c 28$ sequences depending on geographical area were noticed earlier [29]. It would be interesting to explore this DNA marker in studies on piroplasmid diversity in other Northern European and Baltic countries and to determine whether these sequence types could be region specific. Additionally, two members of the $B c 28$ gene family were characterized as major merozoite surface antigens playing a critical function in the interaction of merozoites with red blood cells [35]. Recently, Bc28 protein family members, which are secreted into the host bloodstream, were shown to be potential virulence factors [36]. However, it is still unknown whether the variability of the $B c 28$ gene family could have any impact on the course of the disease or virulence of $B$. canis; future studies to address these questions are required. Additionally, several DNA markers are currently used for phylogenetic studies on B. canis; however, as efficiently highlighted by recent studies, the available sequence information is scarce, and more research is needed to identify highly specific and sensitive $B$. canis population variability markers [37, 38].

In parallel, the $A$. phagocytophilum $m d h$ housekeeping gene, which encodes an enzyme catalyzing $\mathrm{NAD}+/ \mathrm{NADH}$-dependent conversion of malate to oxaloacetate in various metabolic pathways, used in the MLST scheme designed for molecular characterization of $A$. phagocytophilum, was studied [39, 40]. Housekeeping genes are known to be highly conserved 


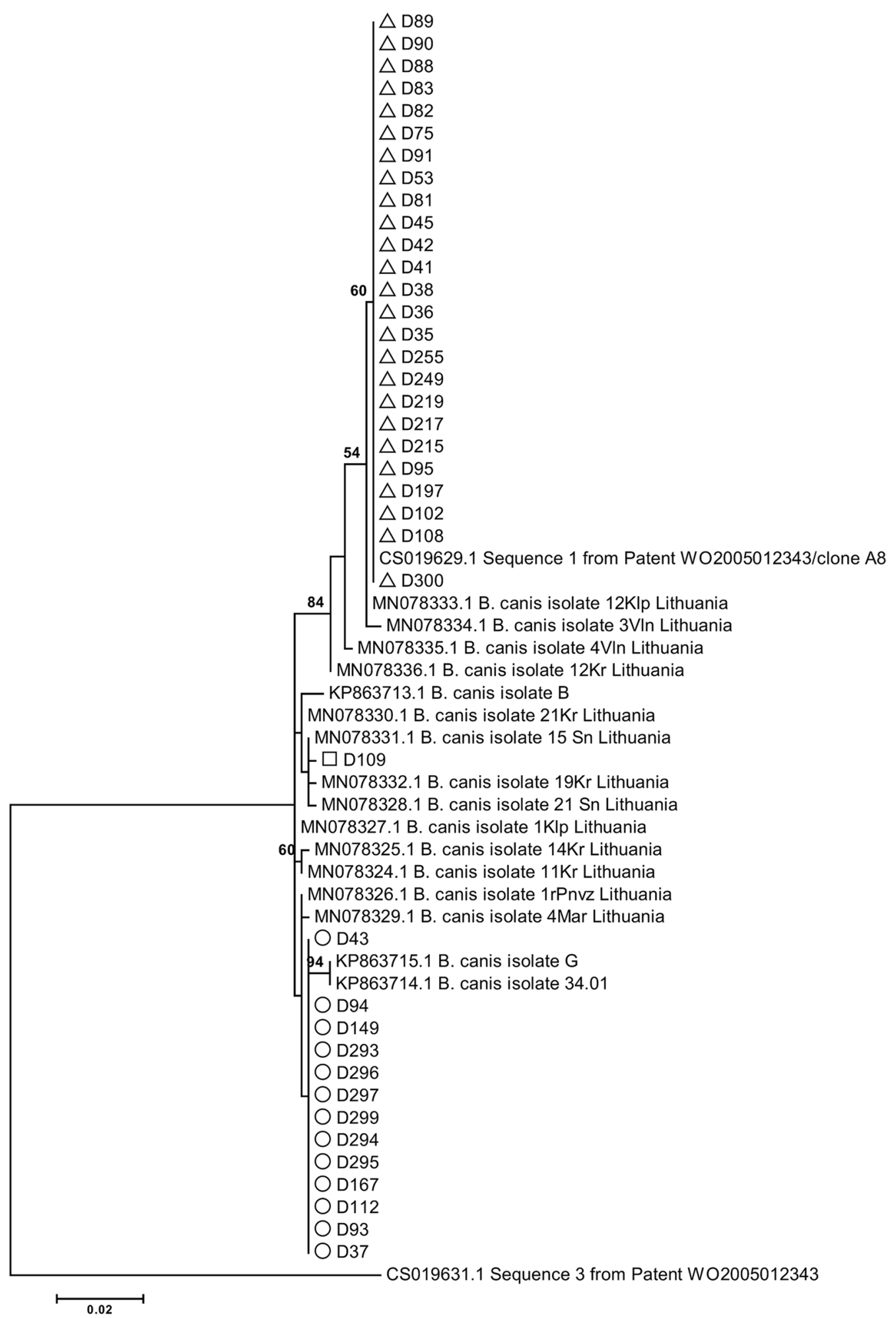

Fig. 1 Molecular phylogenetic analysis of B. canis Bc28.1 gene sequences. The evolutionary history was inferred by using the maximum likelihood method based on the Jukes-Cantor model. The tree with the highest log likelihood (-1361.7900) is shown. The percentage of trees in which the associated taxa clustered together is shown next to the branches. The tree is drawn to scale, with branch lengths measured in the number of substitutions per site. All positions containing gaps, and missing data were eliminated. There were a total of 629 positions in the final dataset. Bootstrap values $<50 \%$ were omitted. B. canis isolates from this study were indicated by white triangles (isolate D197 type), white circles (isolate D93 type) and white square (isolate D109) 


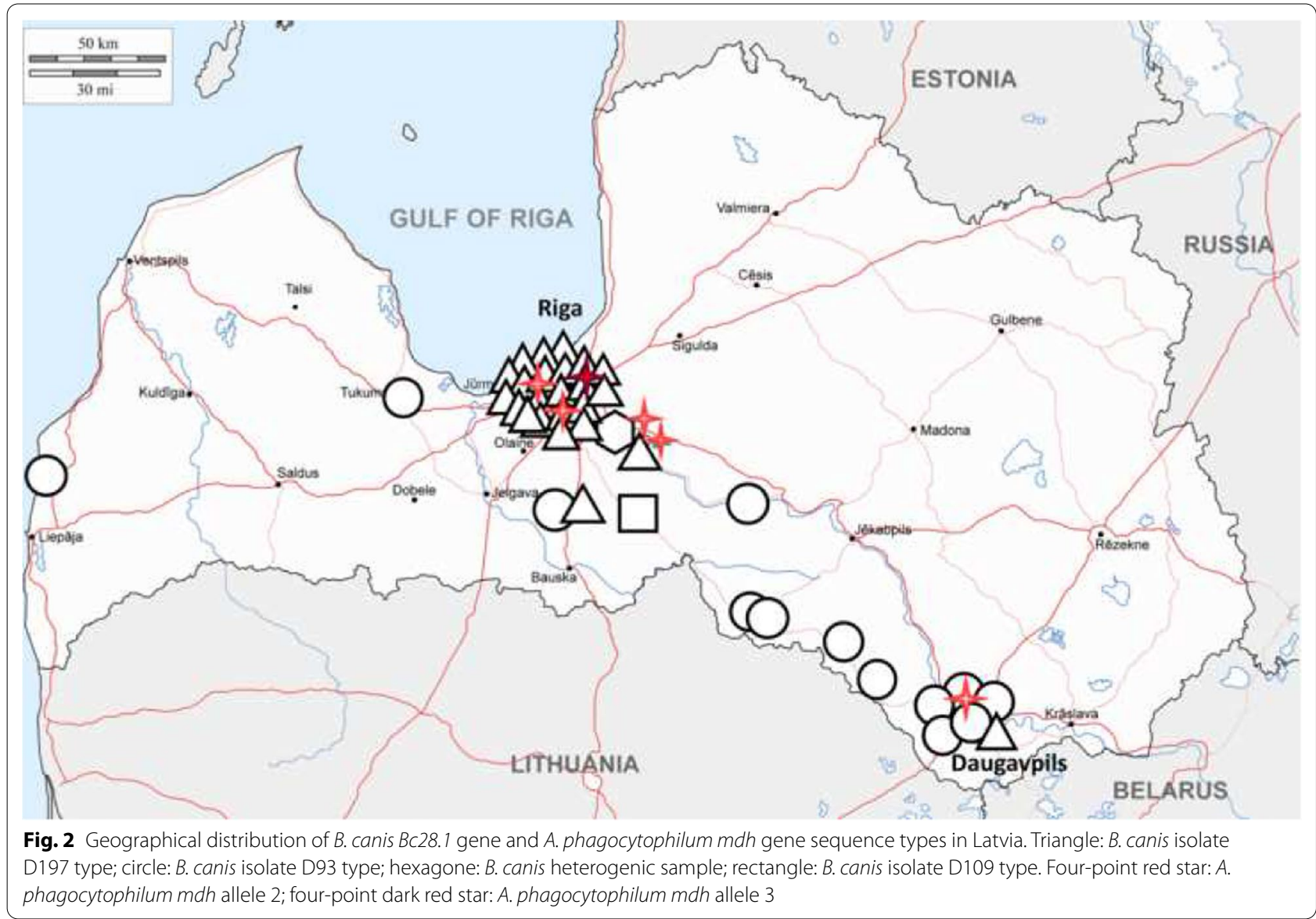

and have a low degree of variation. However, our sequence-based phylogenetic analysis of the $m d h$ gene revealed that dogs were infected with two different $A$. phagocytophilum types belonging to the MLST database-based $m d h$ gene clusters 2 and 3. Both $m d h$ alleles 2 and 3 were described in different animals, including dogs, from numerous European countries and also were reported in humans. The presence of the widespread $A$. phagocytophilum strains in Latvian dogs is not surprising, and this finding could be of both veterinary and medical interest. Previous studies of the European A. phagocytophilum strains suggested the presence of different genetic variants and a correlation of these with the vertebrate hosts and tick vectors and also a possible correlation with geographical origin [41]. Thus, it would be important to explore the diversity of $A$. phagocytophilum in Latvia in more detail in future studies.

Based on the obtained results within this study, it was decided that the $B c 28.1$ and $m d h$ genes could be an appropriate and selective molecular targets of a novel RT-PCR method aiming for the detection of $B$. canis and $A$. phagocytophilum in clinical samples. At least seven $B c 28$ gene copies are present in the $B$. canis genome, which probably could have a positive impact on the sensitivity of the molecular method [42]. Also, the low variability of the $m d h$ gene could be considered a benefit for diagnostic purposes. The developed assay for simultaneous detection of both A. phagocytophilum and B. canis demonstrated high

(See figure on next page.)

Fig. 3 Molecular phylogenetic analysis of A. phagocytophilum mdh gene sequences. The evolutionary history was inferred using the maximum likelihood method based on the Hasegawa-Kishino-Yano model. The tree with the highest log likelihood (-1159.3952) is shown. The percentage of trees in which the associated taxa clustered together is shown next to the branches. The tree is drawn to scale, with branch lengths measured in the number of substitutions per site. All positions containing gaps and missing data were eliminated. There were a total of 387 positions in the final dataset. Bootstrap values $<50 \%$ were omitted. A. phagocytophilum isolates from this study were indicated by black triangles 


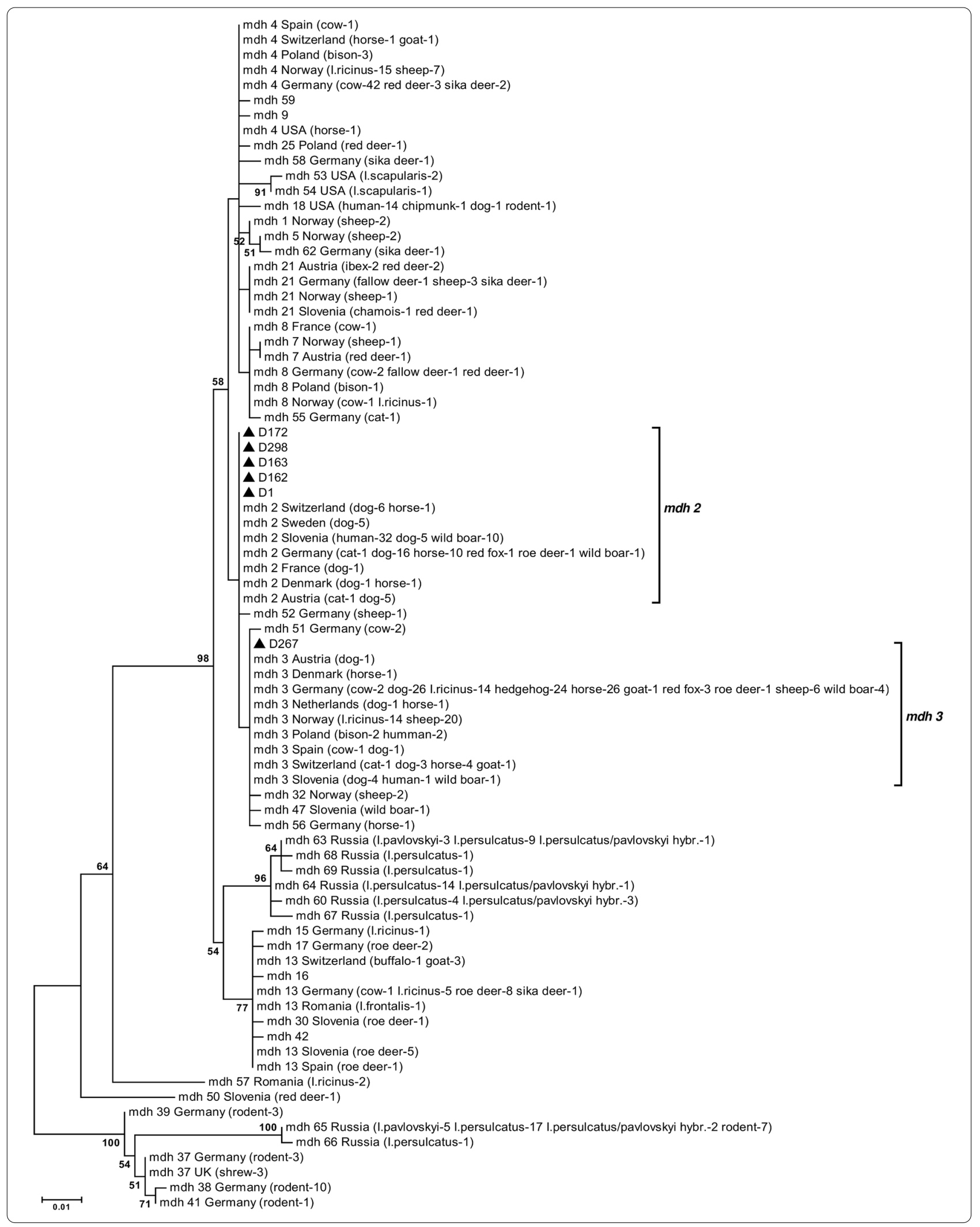


Table 3 Lower limit of detection (LOD) of the RT-PCR assay for B. canis and A. phagocytophilum using 20 intra-assay replicates at two different concentration levels

\begin{tabular}{llllll}
\hline $\begin{array}{l}\text { Gene } \\
\text { copies/ } \\
\text { reaction }\end{array}$ & B.canis Bc28 gene & & \multicolumn{2}{l}{$\begin{array}{l}\text { A. phagocytophilum mdh } \\
\text { gene }\end{array}$} \\
\cline { 2 - 3 } & Mean Ct \pm SD & LOD, \% & & Mean Ct $\pm S D$ & LOD, \% \\
\hline 10 & $29.629 \pm 1.058$ & $\begin{array}{c}(20 / 20) \\
100 \%\end{array}$ & & $32.073 \pm 0.997$ & $(20 / 20) 100 \%$ \\
5 & $33.197 \pm 1.044$ & $(18 / 20) 90 \%$ & & $34.141 \pm 0.522$ & $(14 / 20) 70 \%$
\end{tabular}

Table 4 Characterisation of the sample sets used for clinical specificity assessment of the RT-PCR method

\begin{tabular}{cccccc}
\hline & $\begin{array}{l}\text { A. phagocytophilum- } \\
\text { positive }\end{array}$ & $\begin{array}{l}\text { B. canis- } \\
\text { positive }\end{array}$ & $\begin{array}{l}\text { Pathogen- } \\
\text { negative }\end{array}$ & Total & $\begin{array}{l}\text { Correctly } \\
\text { classified }\end{array}$ \\
\hline $\begin{array}{c}\text { Sample } \\
\text { set no. } 1\end{array}$ & 5 & 40 & 212 & 257 & 257 \\
$\begin{array}{c}\text { Sample } \\
\text { set no. 2 }\end{array}$ & 1 & 2 & 91 & 94 & 94 \\
\hline
\end{tabular}

analytical sensitivity and was suitable for clinical samples. The LOD for both pathogens reached ten gene copies per reaction, and it was able to correctly classify positive and negative clinical samples. These results suggest that the $B c 28.1$ and $m d h$ genes appear to be good candidates for novel diagnostic strategies.

Duplex and multiplex RT-PCR tests could be beneficial in particular circumstances and settings such as when the risk of coinfection exists. Indeed, the presence of mixed infection of $B$. canis and A. phagocytophilum and triple infection with Dirofilaria repens, A. phagocytophilum and B. canis was detected in dogs in Slovakia [43, 44], and it was reported that outdoor dogs in Serbia are frequently exposed to the Anaplasma and Babesia genera [45]. A. phagocytophilum is widespread in Europe, while B. canis has been described across most of Europe with higher prevalence in central Europe $[1,10]$. Coinfections with vector-borne pathogens may produce more severe clinical signs and alter clinical disease manifestations typically associated with singular infections thereby complicating diagnosis and treatment [46-49]. Thus, the duplex RT-PCR assay could provide suitable for simultaneous species-specific detection of B. canis and A. phagocytophilum infections in clinical samples and in screening studies of asymptomatic infections in dogs.

The limitation of this study was the inability to validate the RT-PCR method for the quantification of target gene copies in clinical samples, as the main purpose of the research was to develop and validate a qualitative method. In the future, it could be useful to upgrade this method and measure the exact quantity of pathogen DNA to evaluate the level of parasitemia/ bacteremia.

\section{Conclusions}

A novel duplex RT-PCR molecular method was developed for the detection of B. canis and A. phagocytophilum in canine clinical samples. Sequence variability of $B c 28.1$ and $m d h$ genes indicated the genetic variability of $B$. canis and $A$. phagocytophilum isolates occurring in Latvian domestic dogs.

\section{Abbreviations \\ RT-PCR: Real-time polymerase chain reaction; MLST: Multilocus sequence typing; BLAST: Basic Logical Alignment Search Tool; LOD: Lower limit of} detection.

\section{Supplementary Information}

The online version contains supplementary material available at https:// doi.org/10.1186/s13071-021-04756-9.

Additional file 1: Figure S1. Linearity of the novel duplex RT-PCR assay. Panel A: B. canis. Panel B: A. phagocytophilum.

Additional file 2: Figure S2. Specificity of the novel duplex RT-PCR assay. Representative results of the assay are shown. Abbreviations: $A$. phagocytophilum, A. platys, B. canis, B. vulpes, E. canis: pathogen-positive DNA samples. NK: negative control. Neg_DNA: pathogen-negative DNA sample. PK_BC28: recombinant plasmid standard control with BC28.1 gene insert. PK_MDH: recombinant plasmid standard control with mah gene insert.

\section{Acknowledgements}

The authors thank all veterinarians and pet owners for collecting and providing clinical samples.

\section{Authors' contributions}

VC and RR planned the study. AK, AN, MS, SA and VC performed sample collection, DNA extraction, PCR, sequencing, phylogenetic and data analysis. AK performed RT-PCR. AK and RR wrote the manuscript. All authors read and approved the final manuscript.

\section{Funding}

This work was supported by the ERDF project no. 1.1.1.1/16/A/044. The funders of the study had no role in the study design, analysis or writing of the report.

\section{Availability of data and materials}

All data generated or analyzed during this study are included in this published article.

\section{Declarations}

Ethics approval and consent to participate

Not applicable.

\section{Consent for publication}

Not applicable.

\section{Competing interests}

The authors declare that they have no competing interests. 
Received: 7 December 2020 Accepted: 29 April 2021

Published online: 20 May 2021

\section{References}

1. Solano-Gallego L, Sainz A, Roura X, Estrada-Pena A, Miro G. A review of canine babesiosis: the European perspective. Parasit Vectors. 2016;9:336.

2. Villiers E, Blackwood L. BSAVA Manual of canine and feline clinical pathology. 2nd ed. West Sussex: Wiley; 2005. p. 428-9.

3. Foldivari G, Siroky P, Szekeres S, Majoros G, Sprong H. Dermacentor reticulatus: a vector on the rise. Parasit Vectors. 2016;9:314

4. Radzijevskaja J, Mardosaite-Busaitiene D, Aleksandravičiene A, Paulauskas A. Investigation of Babesia spp. in sympatric populations of Dermacentor reticulatus and Ixodes ricinus ticks in Lithuania and Latvia. Ticks Tick Borne Dis. 2018;9:270-4.

5. Seleznova M, Kivrane A, Namina A, Krumins R, Aleinikova D, Lazovska M, et al. Babesiosis in Latvian domestic dogs, 2016-2019. Ticks Tick Borne Dis. 2020:11:101459.

6. Namina A, Capligina V, Seleznova M, Krumins R, Aleinikova D, Kivrane A, et al. Tick-borne pathogens in ticks collected from dogs, Latvia, 2011-2016. BMC Vet Res. 2019;15:398.

7. Paulauskas A, Radzijevskaja J, Karveliene B, Grigonis A, Aleksandraviciene $A$, Zamokas $G$, et al. Detection and molecular characterization of canine babesiosis causative agent Babesia canis in the naturally infected dog in Lithuania. Vet Parasitol. 2014;205:702-6.

8. Berzina I, Capligina V, Baumanis V, Ranka R, Cirule D, Matise I. Autochtonous canine babesiosis caused by Babesia canis canis in Latvia. Vet Parasitol. 2013;196:515-8.

9. Tiskina V, Capligina V, Must K, Berzina I, Ranka R, Jokelainen P. Fatal Babesia canis canis infection in a splenectomized Estonian dog. Acta Vet Scand. 2016:58:7.

10. Stuen S, Granquist EG, Silaghi C. Anaplasma phagocytophilum - a widespread multi-host pathogen with highly adaptive strategies. Front Cell Infect Microbiol. 2013;3:31.

11. Sainz A, Roura X, Miro G, Estrada-Pena A, Kohn B, Harrus S, SolanoGallego L. Guideline for veterinary practitioners on canine ehrlichiosis and anaplasmosis in Europe. Parasit Vectors. 2015;8:75.

12. Berzina I, Capligina V, Bormane A, Pavulina A, Baumanis V, Ranka R, et al. Association between Anaplasma phagocytophilum seroprevalence in dogs and distribution of Ixodes ricinus and Ixodes persulcatus ticks in Latvia. Ticks Tick Borne Dis. 2013;4:83-8.

13. Capligina V, Seleznova M, Akopjana S, Freimane L, Lazovska M, Krumins $\mathrm{R}$, et al. Large-scale countrywide screening for tick-borne pathogens in field-collected ticks in Latvia during 2017-2019. Parasit Vectors. 2020;13:351

14. Pantchev N, Pluta S, Huisinga E, Nather S, Scheufelen M, Vrhovec MG, et al. Tick-borne diseases (borreliosis, anaplasmosis, babesiosis) in German and Austrian dogs: status quo and review of distribution, transmission, clinical findings, diagnostics and prophylaxis. Parasitol Res. 2015;114(Suppl 1):S19-54.

15. Annoscia G, Latrofa MS, Cantacessi C, Olivieri E, Manfredi MT, Dantas-Torres F, Otranto D. A new PCR assay for the detection and differentiation of Babesia canis and Babesia vogeli. Ticks Tick Borne Dis. 2017:86:862-5

16. Casati S, Sager H, Gern L, Piffaretti JC. Presence of potentially pathogenic Babesia sp. for human in Ixodes ricinus in Switzerland. Ann Agric Environ Med. 2006;13:65-70.

17. Birkenheuer AJ, Levy MG, Breitschwerdt EB. Development and evaluation of a seminested PCR for detection and differentiation of Babesia gibsoni (Asian genotype) and B. canis DNA in canine blood samples. J Clin Microbiol. 2003;41:4172-7.

18. Jefferies R, Ryan UM, Irwin PJ. PCR-RFLP for the detection and differentiation of the canine piroplasm species and its use with filter paper-based technologies. Vet Parasitol. 2007;144:20-7.

19. Duarte SC, Linhares GF, Romanowsky TN, da Silveira Neto OJ, Borges LM. Assessment of primers designed for the subspecies-specific discrimination among Babesia canis canis, Babesia canis vogeli and Babesia canis rossi by PCR assay. Vet Parasitol. 2008;152:16-20.
20. Massung RF, Slater K, Owens JH, Nicholson WL, Mather TN, Solberg VB, et al. Nested PCR assay for detection of granulocytic ehrlichiae. J Clin Microbiol. 1998;36:1090-5.

21. Liz JS, Sumner JW, Pfister K, Brossard M. PCR detection and serological evidence of granulocytic ehrlichial infection in roe deer (Capreolus capreolus) and chamois (Rupicapra rupicapra). J Clin Microbiol. 2002;40:892-7.

22. Liz JS, Anderes L, Sumner JW, Massung RF, Gern L, Rutti B, Brossard M. PCR detection of granulocytic ehrlichiae in Ixodes ricinus ticks and wild small mammals in western Switzerland. J Clin Microbiol. 2000;38:1002-7.

23. Costa LM Jr, Zahler-Rinder M, Ribeiro MF, Rembeck K, Rabelo EM, Pfister K, Passos LM. Use of a real time PCR for detecting subspecies of Babesia canis. Vet Parasitol. 2012;188:160-3.

24. Qurollo BA, Archer NR, Schreeg ME, Marr HS, Birkenheuer AJ, Haney $\mathrm{KN}$, et al. Improved molecular detection of Babesia infections in animals using a novel quantitative real-time PCR diagnostic assay targeting mitochondrial DNA. Parasit Vectors. 2017;10:128.

25. Stanczak J, Cieniuch S, Lass A, Biernat B, Racewicz M. Detection and quantification of Anaplasma phagocytophilum and Babesia spp. in Ixodes ricinus ticks from urban and rural environment, northern Poland, by real-time polymerase chain reaction. Exp Appl Acarol. 2015;66:63-81.

26. Santos HA, Pires MS, Vilela JA, Santos TM, Faccini JL, Baldani CD, et al. Detection of Anaplasma phagocytophilum in Brazilian dogs by realtime polymerase chain reaction. J Vet Diagn Invest. 2011;23:770-4.

27. Courtney JW, Kostelnik LM, Zeidner NS, Massung RF. Multiplex realtime PCR for detection of Anaplasma phagocytophilum and Borrelia burgdorferi. J Clin Microbiol. 2004;42:3164-8.

28. Shen Z, Zhang MZ, Stich RW, Mitchell WJ, Zhang S. Development of a tick-borne pathogen QPCR panel for detection of Anaplasma Ehrlichia, Rickettsia, and Lyme disease Borrelia in animals. J Microbiol Methods. 2018;151:83-9.

29. Carcy B, Randazzo S, Depoix D, Adaszek L, Cardoso L, Baneth G, et al. Classification of Babesia canis strains in Europe based on polymorphism of the $B c 28.1$ gene from the Babesia canis $B c 28$ multigene family. Vet Parasitol. 2015;211:111-23.

30. Jolley KA, Bray JE, Maiden MCJ. Open-access bacterial population genomics: BIGSdb software, the PubMLST.org website and their applications. Wellcome Open Res. 2018;3:124.

31. Thompson JD, Higgins DG, Gibson TJ. CLUSTAL W: improving the sensitivity of progressive multiple sequence alignment through sequence weighting, position-specific gap penalties and weight matrix choice. Nucleic Acids Res. 1994;22:4673-80.

32. Jukes TH, Cantor CR. Evolution of protein molecules. Mammalian protein metabolism. New York: Academic Press; 1969.

33. Hasegawa M, Kishino H, Yano T. Dating the human-ape split by a molecular clock of mitochondrial DNA. J Mol Evol. 1985;22:160-74.

34. Kumar S, Stecher G, Tamura K. MEGA7: Molecular evolutionary genetics analysis version 7.0 for bigger datasets. Mol Biol Evol. 2016:33:1870-4.

35. Yang YS, Murciano B, Moubri K, Cibrelus P, Schetters T, Gorenflot $A$, et al. Structural and functional characterization of $B c 28.1$, major erythrocyte-binding protein from Babesia canis merozoite surface. J Biol Chem. 2012;287:9495-508.

36. Eichenberger RM, Ramakrishnan C, Russo G, Deplazes P, Hehl AB. Genome-wide analysis of gene expression and protein secretion of Babesia canis during virulent infection identifies potential pathogenicity factors. Sci Rep. 2017;7:3357.

37. Hrazdilová K, Myśliwy I, Hildebrand J, Buńkowska-Gawlik K, Janaczyk B, Perec-Matysiak A, Modrý D. Paralogs vs genotypes? Variability of Babesia canis assessed by $18 \mathrm{~S}$ rDNA and two mitochondrial markers. Vet Parasitol. 2019;266:103-10.

38. Hrazdilová K, Rybáŕová M, Široký P, Votýpka J, Zintl A, Burgess H, et al. Diversity of Babesia spp. in cervid ungulates based on the $18 \mathrm{~S}$ rDNA and cytochrome coxidase subunit I phylogenies. Infect Genet Evol. 2020;77:104060

39. Huhn C, Winter C, Wolfsperger T, Wüppenhorst N, Strašek Smrdel K, Skuballa J, et al. Analysis of the population structure of Anaplasma 
phagocytophilum using multilocus sequence typing. PLoS One. 2014;9:e93725.

40. Takahashi-Iniguez T, Aburto-Rodríguez N, Vilchis-Gonzalez AL, Flores ME. Function, kinetic properties, crystallization, and regulation of microbial malate dehydrogenase. J Zhejiang Univ Sci B. 2016;17:247-61.

41. Matei IA, Estrada-Peña A, Cutler SJ, Vayssier-Taussat M, Varela-Castro L, Potkonjak A, et al. A review on the eco-epidemiology and clinical management of human granulocytic anaplasmosis and its agent in Europe. Parasit Vectors. 2019;12:599.

42. Carcy B, Precigout E, Schetters T, Gorenflot A. Genetic basis for GPIanchor merozoite surface antigen polymorphism of Babesia and resulting antigenic diversity. Vet Parasitol. 2006;138:33-49.

43. Majláthová V, Majláth I, Víchová B, Gul'ová I, Derdáková M, Sesztáková E, Pet'ko B. Polymerase chain reaction confirmation of Babesia canis canis and Anaplasma phagocytophilum in dogs suspected of babesiosis in Slovakia. Vector Borne Zoonotic Dis. 2011;11:1447-51.

44. Víchová B, Miterpáková M, Iglódyová A. Molecular detection of co-infections with Anaplasma phagocytophilum and/or Babesia canis canis in Dirofilaria-positive dogs from Slovakia. Vet Parasitol. 2014;203:167-72.

45. Kovačević Filipović MM, Beletić AD, llić Božović AV, Milanović Z, Tyrrell P, Buch J, et al. Molecular and serological prevalence of Anaplasma phagocytophilum, A. platys, Ehrlichia canis, E. chaffeenses, E. ewingii, Borrelia burgdorferi, Babesia canis, B. gibsoni and B. vogeli among clinically healthy outdoor dogs in Serbia. Vet Parasitol Reg Stud Reports. 2018;14:117-22.

46. Klag AR, Dunbar LE, Girard CA. Concurrent ehrlichiosis and babesiosis in a dog. Can Vet J. 1991;32:305-7.

47. Tuttle AD, Birkenheuer AJ, Juopperi T, Levy MG, Breitschwerdt EB. Concurrent bartonellosis and babesiosis in a dog with persistent thrombocytopenia. JAVMA. 2003;223:1306-10.

48. Mylonakis ME, Koutinas AF, Baneth G, Polizopoulou Z, Fytianou A. Mixed Ehrlichia canis, Hepatozoon canis, and presumptive Anaplasma phagocytophilum infection in a dog. Vet Clin Pathol. 2004;33:249-51.

49. Baxarias M, Álvarez-Fernández A, Martínez-Orellana P, MontserratSangrà S, Ordeix L, Rojas A, et al. Does co-infection with vector-borne pathogens play a role in clinical canine leishmaniosis? Parasit Vectors. 2018;11:135.

\section{Publisher's Note}

Springer Nature remains neutral with regard to jurisdictional claims in published maps and institutional affiliations. 